\title{
PERILAKU KEWARGAAN ORGANISASI BAGI GURU UNTUK MENINGKATKAN KINERJA PROFESI KEGURUAN
}

\author{
Desy Brema Sevriani Ginting*, Julia Ivanna, Ramsul Nababan \\ Universitas Negeri Medan, Sumatera Utara, Indonesia \\ *gtgdesy@gmail.com
}

\begin{abstract}
The teacher is the most important factor in the field of education because the teacher is the driving force of education for students in achieving educational goals. If there is a managerial role from the leader, the teacher will be able to teach the school the best. Therefore, the principal must be able to motivate teachers to improve teacher performance. This article aims to determine the performance of OCB (Organizational Citizenship Behavior) in teacher leadership and integrity. This article uses the literature study method. Therefore, the principal must be able to stimulate teachers to improve their performance.
\end{abstract}

Keywords: organizational citizenship behaviour, teacher performance

\begin{abstract}
Abstrak
Guru adalah faktor yang terpenting dalam bidang pendidikan, karena guru adalah penggerak pendidikan bagi siswa mencapai tujuan pendidikan. Dalam hal peran manajerial dari pemimpin maka guru akan mampu melakukan pengajaran yang terbaik sekolah. Oleh karena itu, kepala sekolah harus mampu memotivasi guru dalam meningkatkan kinerja guru. Artikel ini bertujuan untuk mengetahui kinerja perilaku kewargaan organisasi dalam kepemimpinan dan integritas guru. Artikel ini menggunakan metode studi kepustakaan. Karena itu, kepala sekolah harus bisa merangsang guru untuk meningkatkan kinerjanya.
\end{abstract}

Kata kunci: perilaku kewargaan organisasi, kinerja guru.

\section{PENDAHULUAN}

Pendidikan merupakan hal terpenting dalam hidup kita, artinya setiap orang berhak atas pendidikan. Secara umum, pendidikan mengacu pada proses kehidupan mengembangkan diri setiap orang untuk hidup dan terus hidup. Sejalan dengan pembukaan keempat Undang-Undang Dasar Negara Republik Indonesia Tahun 1945 yang menyebutkan tujuan bangsa Indonesia adalah mencerdaskan kehidupan bangsa.

Pendidikan dapat diperoleh dari lingkungan keluarga dan lingkungan masyarakat, namun yang terpenting adalah mendidik di lingkungan sekolah. Pendidikan di lingkungan sekolah memang membutuhkan perhatian pemerintah guna mencapai tujuan nasional. Untuk itu diperlukan sumber daya manusia yang berkualitas. Dalam hal ini guru merupakan salah satu bagian terpenting dalam pendidikan, karena guru memegang peranan strategis dalam peningkatan mutu pendidikan, karena guru berhubungan 
langsung dengan peserta didik, sekaligus melaksanakan pendidikan iptek yang bernilai positif, tanpa melupakan unsur lain, antara lain tujuan pendidikan, peserta didik, mata pelajaran, lingkungan pendidikan, serta interaksi pendidikan dan alat pendidikan.

Guru adalah salah satu elemen kunci dalam sistem pendidikan (khususnya sekolah). Jika sifat pembelajaran, yaitu interaksi guru-siswa tidak memenuhi syarat, semua komponen lain mulai dari kurikulum, infrastruktur, biaya, dll, tidak akan masuk akal. Nyatanya, semakin banyak orang yang menyadari bahwa tidak ada guru dan tidak ada pendidikan formal. Tanpa jumlah guru profesional yang memadai, tidak akan ada pendidikan yang berkualitas. Peran guru dalam mentransformasi investasi pendidikan sangat penting sehingga banyak ahli menyatakan bahwa di sekolah, kualitas guru tidak akan berubah atau ditingkatkan tanpa adanya perubahan dan peningkatan kualitas guru.

Supadi \& Listyasari (2018) berpendapat guru memiliki peran strategis dalam menentukan mutu pendidikan. Hal ini terkait dengan peran penting guru dalam menyampaikan pengetahuan kepada siswa, dan merupakan posisi yang paling aktif untuk berinteraksi dengan siswa. Keadaan ini menjadikan status guru sangat penting dalam proses pendidikan dan pembelajaran. Dalam kondisi seperti itu, guru memiliki andil besar dalam mencapai tujuan sekolah sebagai lembaga pendidikan dan pusat pembelajaran. Karena itu, guru dituntut untuk memainkan peran tambahan yang dibutuhkan oleh sektor pendidikan.

Selain modal sosial dan kecerdasan emosional, guru juga harus berkontribusi dalam pencapaian tujuan organisasi sekolah. Melalui kerja sukarela untuk membantu siswa, kolega, dan sekolah, menunjukkan kemauan untuk melampaui tanggung jawab utama mereka, menjaga kepentingan organisasi sekolah, dan mempromosikan diri, siswa, dan organisasi untuk memikul tanggung jawab yang lebih besar. Tentunya para guru membutuhkan perilaku tersebut untuk mencapai tujuan sekolah. Robbins \& Judge (2008) memberikan dukungan untuk hal tersebut, yaitu organisasi dengan Organizational Citizenship Behavior (selanjutnya, OCB/perilaku kewarganegaraan organisasi) yang tinggi akan berkinerja lebih baik dari organisasi lain. Perilaku OCB disebut perilaku warga organisasi. Melalui perilaku kewargaan organisasional, kinerja sosial dapat ditingkatkan sehingga merangsang modal sosial dan kecerdasan emosional.

Faktor yang mendukung tercapainya kinerja guru adalah adanya perilaku warga organisasi dalam diri guru atau pendidik. Dalam hal ini setiap pimpinan berkewajiban untuk menunjukkan kepedulian kepada guru agar dapat bekerja sesuai dengan petunjuk yang diberikan sehingga tercipta kondisi dan lingkungan kerja, dan mendorong perkembangan kegiatan kerja untuk secara efektif mencapai tujuan sekolah.

Penguasaan kemampuan yang memadai tidak sepenuhnya mendukung kinerja guru, sehingga perlu dilakukan upaya yang komprehensif untuk meningkatkan kemampuan guru. Jika guru melaksanakan tugas-tugas berikut, antara lain loyalitas dan komitmen tinggi terhadap tugas mengajar, menguasai dan mengembangkan materi pembelajaran, disiplin mengajar dan tugas-tugas lainnya, mengerahkan kreativitas dalam pelaksanaan pembelajaran, dan bekerjasama dengan seluruh warga sekolah, maka dapat dikatakan kinerja guru tersebut baik. Kepemimpinan guru menjadi panutan bagi siswa, berkepribadian baik, jujur dan objektif kepada siswa, serta tanggung jawab terhadap tugasnya sendiri. 
Purba \& Seniati (2004) menjelaskan perilaku yang dimaksudkan sebagai OCB juga merupakan perilaku individu, dan individu harus melampaui apa yang harus dia lakukan untuk menunjukkan individu terbaiknya. Extra role behavior merupakan perilaku dalam bekerja, tidak termasuk dalam job description resmi pegawai, namun jika ditampilkan oleh pegawai akan sangat dihargai, karena dapat meningkatkan efektivitas dan kelangsungan organisasi.

Kinerja perilaku warga organisasi (OCB) sebagai bagian dari perilaku extra-role juga memerlukan perhatian khusus. Hal ini dikarenakan kurangnya motivasi guru untuk melakukan perilaku peran ekstra di sekolah. Sebagian besar guru dipaksa untuk melakukan perilaku peran tambahan, bukan karena mereka mau dan ingin mendorong perkembangan sekolah. Dari uraian di atas, terlihat bahwa kinerja guru kurang memadai, karena guru kurang memahami peran guru.Sikap tidak peduli terhadap visi dan misi sekolah turut berperan dalam rendahnya kinerja, dan kebijakan kepemimpinan tidak menyentuh motivasi dasar guru untuk berinovasi guna meningkatkan kualitas kerja guru.

\section{PEMBAHASAN}

\section{Guru Sebagai Tenaga Pendidik}

Undang-Undang Republik Indonesia Nomor 20 Tahun 2003 tentang Sistem Pendidikan Nasional (selanjutnya, UU Sisdiknas) menjelaskan guru termasuk dalam kategori pendidik. Padahal guru dan pendidik adalah dua hal yang berbeda, istilah pendidik (dalam bahasa Indonesia) adalah pedanan, dan istilah pendidik (dalam bahasa Inggris). Danim (2010, hal. 17) mengatakan dalam kamus webster, istilah educator adalah educationist atau educationalist, yaitu pendidik dalam bahasa Indonesia. Istilah guru (bahasa Indonesia) sama dengan teacher (bahasa Inggris). Dalam kamus Webster, kata "guru" berarti "terutama seseorang yang mengajar di sekolah", atau guru adalah orang yang mengkhususkan diri dalam mengajar di sekolah. Menurut Pasal 39 (2) UU Sisdiknas menyebutkan "pendidik merupakan tenaga profesional yang bertugas merencanakan dan melaksanakan proses pembelajaran, menilai hasil pembelajaran, melakukan pembimbingan dan pelatihan, serta melakukan penelitian dan pengabdian kepada masyarakat, terutama bagi pendidik pada perguruan tinggi".

Pasal 1 (1) Peraturan Pemerintah Republik Indonesia Nomor 19 Tahun 2017 yang mengatur Perubahan Peraturan Pemerintah Nomor 74 Tahun 2008 tentang Guru (selanjutnya PP Guru) menyebutkan bahwa "guru adalah pendidik dan guru yang menyelenggarakan pendidikan anak usia dini melalui sekolah atau pendidikan formal, pendidikan dasar dan pendidikan menengah". Guru karenanya guru harus memenuhi standar kualifikasi profesional. Secara garis besar, siapapun yang mengajarkan hal-hal baru juga bisa dianggap sebagai guru. Secara formal, guru mengacu pada guru di sekolah negeri atau swasta yang memiliki kemampuan menjadi guru berdasarkan latar belakang pendidikan formal minimal sarjana, dan memiliki persyaratan hukum untuk menjadi guru berdasarkan Undang-Undang Republik Indonesia Nomor 14 Tahun 2005 tentang Guru (selanjutnya UU Guru dan Dosen) yang berlaku di Indonesia saat ini. Guru merupakan kunci utama peningkatan mutu pendidikan, karena syarat penting untuk mencapai pendidikan yang bermutu adalah pendidikan harus dilaksanakan oleh tenaga pendidik yang dapat mengandalkan profesionalitasnya. 
Dalam proses pelaksanaannya diperlukan perubahan sikap dan perilaku seluruh departemen sekolah, termasuk kepala sekolah, guru dan penyelenggara, termasuk orang tua dan masyarakat, dalam hal pengamatan, pemahaman dan pendampingan, serta supervisi dan evaluasi penyelenggaraan sekolah. Heryati \& Muhsin (2014) meyakini bahwa tenaga pengajar adalah orang yang terlibat dalam tugas pendidikan yaitu guru/dosen, manajer/administrator, pengawas dan pegawai. Perlu melatih pendidik untuk lebih bekerja sama dengan masyarakat. Menurut UU Sisdiknas, tugas dan fungsi pendidik dan pendidik adalah: (1) pendidik adalah tenaga profesional yang tugasnya merencanakan dan melaksanakan proses pembelajaran, mengevaluasi hasil pembelajaran, melakukan pembinaan dan pelatihan, serta melakukan penelitian dan pengabdian kepada masyarakat, khususnya bagi pendidik di perguruan tinggi dan universitas, (2) tugas pendidik adalah memberikan pelayanan administrasi, pengelolaan, pembinaan, supervisi dan teknis untuk menunjang proses pendidikan di bidang pendidikan.

Nur (2009) mengemukakan tugas dan tanggung jawab pendidik: (1) Dalam jalur pendidikan formal yang bertanggung jawab atas pendidikan dasar dan menengah (termasuk pendidikan anak usia dini), guru bertanggung jawab sebagai agen pembelajaran dan bertanggung jawab untuk memotivasi, mempromosikan, mendidik, membimbing dan melatih siswa sehingga mereka dapat menjadi orang yang berkualitas; sementara (2) Dosen bertugas dan bertanggung jawab sebagai agen pembelajaran, memotivasi, membina mahasiswa pada jenjang pendidikan yang lebih tinggi, sehingga menjadi insan yang berkualitas, yang mampu mengembangkan potensi insani sebaikbaiknya dan berkontribusi pada perkembangan sains, teknologi/ atau seni dengan melakukan penelitian, dan melakukan pengabdian masyarakat; (3) Konselor memiliki tugas dan tanggung jawab untuk memberikan layanan bimbingan dan konsultasi bagi siswa di satuan pendidikan dasar, menengah, dan tinggi; (4) Pamong pembelajaran adalah bertanggung jawab dan menginstruksikan, mengajar, melatih siswa dan mengembangkan: model proses pembelajaran, perangkat pembelajaran dan manajemen pembelajaran pada jalur pendidikan informal; (5) Widyaiswara memiliki kewajiban dan tanggung jawab untuk mendidik, mengajar, dan melatih peserta didik dalam program pendidikan dan pelatihan prajabatan dan/atau pemerintah daerah; (6) Pengajar atau tutor bertugas dan bertanggung jawab memberikan bantuan belajar kepada siswa dalam proses belajar mandiri atau dalam proses belajar kelompok di satuan pendidikan formal dan nonformal; (7) Instruktur bertugas dan bertanggung jawab untuk memberikan pelatihan teknis kepada peserta didik dalam kursus atau pelatihan; (8) Fasilitator bertugas dan bertanggung jawab untuk memberikan layanan pembelajaran kepada lembaga pendidikan dan pelatihan; (9) Pelatih memiliki tanggung jawab dan kewajiban untuk memberikan pelatihan teknis olahraga kepada siswa di satuan pendidikan formal maupun nonformal.

\section{Kinerja Guru}

Selain faktor lain seperti siswa, kurikulum, sarana dan prasarana, guru menjadi faktor penting dalam menentukan mutu pendidikan. Guru memegang peran strategis dalam bidang pendidikan, tanpa dukungan guru yang berkualitas, sumber daya pendidikan lain yang sesuai biasanya tidak akan berarti. Dengan kata lain, guru berada di garis depan dalam meningkatkan kualitas layanan dan hasil pendidikan. Oleh karena itu, peningkatan mutu pendidikan sangat erat kaitannya dengan peningkatan kinerja guru. Proses peningkatan kinerja guru telah terbentuk dan berlangsung dalam kegiatan mengajar di tempat kerja. Selain itu, kinerja guru juga dipengaruhi oleh bimbingan dan

\section{JURNAL KEWARGANEGARAAN}


supervisi kepala sekolah (Pidarta, 1992, hal. 3). Tentunya urgensi peningkatan kinerja guru sangat erat kaitannya dengan tanggung jawab pendidik. Dari hal tersebut terlihat bahwa guru dengan kinerja yang tinggi akan mampu mengelola pembelajaran dengan sebaik-baiknya dan mencapai hasil yang maksimal, begitu pula sebaliknya.

Menurut Yamin (2010, hal. 87) kinerja guru adalah suatu perilaku atau reaksi yang hasil kerjanya merepresentasikan pekerjaannya dalam menyelesaikan tugas. Beberapa kegiatan tersebut antara lain; 1) kegiatan sebelum mengajar, 2) kegiatan selama masa mengajar, 3) kegiatan selama tahap mengajar, 4) kegiatan yang berkaitan dengan partisipasi guru di masyarakat, pendidik atau lingkungan yang lebih luas. Supriyatno, Subiyanto, \& Tawil (2016, hal. 173) kinerja merupakan hasil kerja atau prestasi kerja yang dilakukan oleh guru berdasarkan kemampuannya dalam pengelolaan kegiatan belajar mengajar. Mathis, \& Jackson (2006) menjelaskan bahwa kinerja guru mempengaruhi kontribusinya terhadap organisasi.

Menurut Supardi (2016, hal. 73) kinerja guru yang baik harus memenuhi syarat sebagai berikut: (1) Memiliki kemampuan untuk merencanakan dan mempersiapkan pengajaran, (2) Kemampuan melaksanakan pembelajaran, (3) Kemampuan menjalin hubungan interpersonal, (4) Mampu mengevaluasi hasil belajar (5) Kemampuan melaksanakan pengayaan (6) Kemampuan melaksanakan remedial. Kinerja dalam pengertian ini disebut juga prestasi kerja. Kinerja adalah hasil atau keseluruhan tingkat keberhasilan seseorang dalam kurun waktu tertentu untuk menyelesaikan suatu tugas tertentu, seperti standar kerja, indikator atau standar yang telah ditetapkan sebelumnya. Guru yang berprestasi biasa disebut guru profesional (Jalal \& Supriadi, 2001).

UU Guru dan Dosen adalah aturan politik yang mengatur bahwa pendidik adalah pekerja profesional dan berhak menikmati hak dan tugas profesional. Dengan cara ini, diharapkan para pendidik dapat mengabdikan diri pada profesinya dan menjalani kehidupan yang layak dari profesinya tersebut. UU Guru dan Dosen dan menjelaskan bahwa (1) pendidik harus memiliki kualifikasi akademik dan kemampuan sebagai agen pembelajaran; (2) sesuai dengan tanggung jawab guru S2 sebagai dosen, gelar dapat diperoleh melalui pendidikan tinggi program sarjana (S1) atau program diploma empat (D-IV); (3) kemampuan profesional guru meliputi kemampuan mengajar, kemampuan personal, kemampuan profesional dan kemampuan sosial. UU Guru dan Dosen secara holistic muatan segala hal guru dan dosen, namun penulis disini lebih menekankan pembahasan tentang hak dan kewajiban guru dan dosen dalam pendidikan. Hak Guru (Pasal 14 UU Guru dan Dosen) dalam menjalankan tugas profesionalnya, guru berhak untuk: (1) memperoleh penghasilan melebihi batas minimum hidup dan kesejahteraan social; (2) mendapatkan promosi dan penghargaan berdasarkan tanggung jawab pekerjaan dan prestasi; (3) terlindungi dalam pelaksanaan tugas dan hak kekayaan intelektual; (4) mendapatkan kesempatan untuk meningkatkan kompetensi; (5) memperoleh dan memanfaatkan sarana dan prasarana pembelajaran untuk mendukung kelancaran tugas professional; (6) mengevaluasi peserta didik dan berpartisipasi dalam penentuan kelulusan, penghargaan dan/atau sanksi sesuai dengan prinsip pendidikan, kode etik guru dan peraturan perundang-undangan; (7) mendapatkan rasa aman saat menjalankan tugas, (8) Bebas untuk mengatur organisasi professional; (9) Memiliki kesempatan untuk berperan dalam menentukan kebijakan pendidikan; (10) memiliki peluang untuk mengembangkan dan meningkatkan kualifikasi dan kemampuan akademik; (11) mendapatkan pelatihan dan pengembangan profesional di bidangnya masing-masing 
Ketentuan lain mengenai hak guru diatur dalam PP 19 Tahun 2017. Selain hak di atas, guru juga berhak menerima penghasilan dan tunjangan sebagaimana diatur dalam Pasal 15 hingga Pasal 19. Guru berhak menerima penghasilan melebihi kebutuhan seharihari, termasuk upah pokok, upah, dan tunjangan penghasilan lainnya dalam bentuk tunjangan profesi, tunjangan khusus, dan tunjangan lain yang berkaitan dengan mengabdi sebagai guru.

Prestasi guru merupakan tingkah laku guru ketika menjalankan tugasnya sebagai pendidik. Berdasarkan Peraturan Menteri Pendidikan Nasional Nomor 41 Tahun 2007 tentang Satuan Pendidikan Dasar dan Menengah, kinerja guru mengacu pada hasil pengajaran yang dicapai oleh kegiatan yang dilakukan oleh guru dalam memenuhi tugas pokok dan fungsinya. Sebagai hasil logis dari para profesional pendidikan. Mulyasa (2004) berkeyakinan bahwa guru dengan kinerja tinggi akan bersemangat dan akan berusaha meningkatkan kemampuannya dalam merencanakan, melaksanakan, dan mengevaluasi pembelajaran untuk memperoleh hasil kerja yang terbaik. Sejalan dengan itu, Rusman (2009, hal. 319) meyakini bahwa bentuk perilaku yang dilakukan guru dalam proses pembelajaran adalah cara guru merencanakan pembelajaran, melaksanakan kegiatan pembelajaran, mengevaluasi hasil belajar dan melaksanakan pembelajaran lanjutan.

Kewajiban Guru (Pasal 20 UU Guru) menjalankan tugas profesional, guru harus: (1) merencanakan pembelajaran, melaksanakan proses pembelajaran berkualitas tinggi, dan serta mengevaluasi hasil pembelajaran; (2) beradaptasi dengan perkembangan ilmu pengetahuan, teknologi dan seni, meningkatkan dan mengembangkan kualifikasi dan kemampuan akademik secara berkelanjutan; (3) bertindak obyektif dan tidak membedabedakan jenis kelamin, agama, suku, ras, kondisi fisik tertentu atau latar belakang keluarga, dan status sosial ekonomi siswa dalam menempuh pendidikan; (4) menjunjung tinggi peraturan-peraturan undang-undang, hukum dan kode etik guru serta nilai-nilai agama dan etika; (5) menjaga dan memupuk persatuan dan kesatuan bangsa.

PP Guru menjelaskan bahwa beban kerja guru mencakup kegiatan pokok: (1) merencanakan pembelajaran atau pembimbingan; (2) melaksanakan pembelajaran atau pembimbingan; (3) menilai hasil pembelajaran atau pembimbingan; (4) membimbing dan melatih peserta didik; (5) melaksanakan tugas tambahan yang melekat pada pelaksanaan kegiatan pokok sesuai dengan beban kerja guru. Selain itu menurut Astuti \& Dacholfany (2016, hal. 206) kinerja guru merupakan kemampuan dan kewenangan guru dalam melaksanakan kegiatan mengajar, meliputi beberapa indikator: (1) membuat rencana pembelajaran; (2) melaksanakan pembelajaran; (3) melaksanakan evaluasi pembelajaran; (4) melaksanakan tindak lanjut hasil evaluasi pembelajaran. Berdasarkan beberapa sudut pandang di atas, dapat disimpulkan bahwa kinerja adalah tingkat keberhasilan seseorang atau suatu kelompok sesuai dengan standar kinerja tertentu untuk melaksanakan tugas sesuai dengan tanggung jawab dan kewenangannya. Dalam rangka pencapaian tujuan organisasi.

Menurut Mangkunegara (2004, hal. 67) faktor-faktor yang mempengaruhi kinerja guru yaitu: pertama, faktor kemampuan; Secara psikologis, kemampuan guru meliputi kemampuan potensial (IQ) dan kemampuan realistik (pengetahuan + keterampilan). Artinya, guru dengan tingkat pendidikan yang tinggi sesuai dengan bidangnya dan mampu melakukan pekerjaan sehari-hari lebih mudah mencapai hasil yang diharapkan. Oleh karena itu, karyawan perlu diberikan pekerjaan berdasarkan pengetahuan

\section{JURNAL KEWARGANEGARAAN}


profesionalnya. Dengan mengatur guru sesuai bidangnya, mereka mampu membantu meningkatkan efisiensi pembelajaran. Kedua, faktor motivasi; Motivasi dibentuk oleh sikap guru dalam menangani situasi kerja. Motivasi merupakan suatu kondisi yang dapat membuat perkembangan langsung menuju terwujudnya tujuan pendidikan. Dalam bukunya Anwar Prabu, C. Meclelland mengemukakan bahwa terdapat hubungan yang positif antara motivasi berprestasi dan kinerja (Mangkunegara, 2004, hal. 68). Dalam bidang psikologi, masalah motivasi semacam ini selalu mendapat perhatian khusus dari para ahli. Karena motivasi itu sendiri adalah gejala jiwa, dapat mendorong orang untuk melakukan tindakan atau melakukan sesuatu keinginan dan kebutuhan.

Syah, Wardan, Rakhmat, \& Muchlis (1997) percaya bahwa motivasi adalah keadaan internal organisme, apakah itu manusia atau hewan, mendorongnya untuk melakukan sesuatu. Alisuf (1996) meyakini bahwa motivasi adalah keadaan dalam tubuh manusia yang mendorong individu untuk melakukan aktivitas tertentu untuk mencapai tujuan. Guru sebagai pendidik memikul tanggung jawab dan tanggung jawab yang berat. Guru harus sadar bahwa dirinya harus serius, bertanggung jawab, ikhlas, dan tidak ceroboh dalam melakukan tugasnya dengan baik agar siswa dapat dengan mudah menerima semua yang dikatakan guru. Jika ini dilakukan, guru akan berprestasi.

Menurut Nasution (2000), guru berperan penting dalam pengembangan diri anak dengan memberikan berbagai pengetahuan dan keterampilan serta membentuk kepribadian. Oleh karena itu, dibutuhkan seorang guru yang dapat mempersiapkan berbagai kemampuan mendidik dan membimbing siswa dengan membantu mereka mencapai kedewasaan secara mandiri. Guru harus memiliki kemampuan profesional dalam kegiatan pembelajaran, meliputi penguasaan materi pembelajaran, strategi pembelajaran, metode, bimbingan dan konsultasi, serta penilaian pembelajaran. Sebagai pengelola pembelajaran, guru harus mampu mengelola seluruh proses kegiatan pembelajaran dengan menciptakan kondisi pembelajaran agar setiap siswa dapat belajar secara efektif. Dalam perannya sebagai evaluator hasil belajar, guru harus selalu memperhatikan hasil belajar siswa. Informasi yang diperoleh melalui penilaian ini akan digunakan sebagai umpan balik dan sebagai titik awal untuk perbaikan dan penyempurnaan proses pembelajaran guna mencapai prestasi akademik siswa. Selain itu, Mac Leland mengemukakan 6 karakteristik guru dengan motivasi berprestasi tinggi dalam Nasution (2000) yaitu: (1) memiliki rasa tanggung jawab pribadi yang tinggi; (2) berani mengambil resiko; (3) memiliki tujuan yang realistis; (4) menggunakan rencana kerja yang komprehensif untuk berusaha mencapai tujuan; (5) menggunakan umpan balik khusus dalam semua aktivitas pekerjaannya; dan (6) mencari peluang untuk menerapkan rencana yang direncanakan.

Kartini (1985) mengemukakan bahwa faktor-faktor pendukung kinerja guru dibedakan menjadi dua kategori, yaitu: pertama, faktor internal meliputi: (a) kecerdasan: kecerdasan memainkan peran penting dalam berhasil melaksanakan tugas pendidik dalam proses pembelajaran. Semakin kompleks dan makmur tugasnya, semakin tinggi kecerdasan yang dibutuhkan. Orang cerdas yang melakukan tugas-tugas sederhana dan monoton mungkin bosan dan menyebabkan penurunan kinerja, (b) keterampilan dan kecakapan: Orang memiliki keterampilan dan kecakapan yang berbeda. Ini karena perbedaan antara pengalaman dan praktik, (c) bakat: Kecocokan antara bakat dan pilihan pekerjaan memungkinkan seseorang untuk bekerja sesuai dengan pilihan dan keterampilan mereka (d) kemampuan dan minat: persyaratan untuk memperoleh keamanan kerja seseorang adalah tugas dan jabatan yang sesuai dengan kemampuannya. 
Kemampuan dengan minat yang tinggi dapat mendukung pekerjaan yang sudah ditekuni, (e) motivasi: motivasi dapat mendorong pekerjaan seseorang meningkat, (f) kesehatan: kesehatan dapat membantu menyelesaikan proses kerja seseorang. Jika kesehatan terganggu, pekerjaan juga akan terganggu (g) kepribadian: orang yang kuat dan sangat terintegrasi mungkin menghadapi lebih sedikit kesulitan dan akan beradaptasi dengan lingkungan kerja dan berinteraksi dengan rekan kerja untuk meningkatkan pekerjaan mereka, (h) Tujuan kerja: Jika pekerjaan seseorang memenuhi cita-cita, maka tujuan itu dapat tercapai karena ia bekerja keras, dan sepenuh hati. Kedua, faktor eksternal meliputi: (a) lingkungan keluarga: lingkungan keluarga mempengaruhi kinerja seseorang. Ketegangan dalam kehidupan keluarga akan mengurangi keinginan untuk bekerja, (b) lingkungan kerja: lingkungan kerja yang menyenangkan dapat mendorong seseorang untuk bekerja secara maksimal. Tidak jarang seseorang mengalami kekecewaan dan kegagalan di tempat kerja. Lingkungan kerja yang disebutkan di sini adalah semacam situasi kerja, rasa aman, upah yang memadai, peluang pengembangan karir dan rekan kerja yang populer, (c) komunikasi dengan kepala sekolah: komunikasi yang baik di sekolah adalah komunikasi yang efektif. Kurangnya komunikasi yang efektif dapat menyebabkan kesalahpahaman, (d) sarana dan prasarana: Terdapat sarana dan prasarana yang sesuai untuk membantu guru meningkatkan kinerja, khususnya dalam proses pengajaran, (e) kegiatan guru di kelas: Pendidikan harus ditingkatkan secara bertahap. Apabila manajemen sekolah tidak memberikan peluang bagi tumbuh dan berkembangnya kreativitas guru maka motivasi guru dalam pengembangan rencana pembelajaran tidak akan ada artinya untuk meningkatkan proses dan hasil belajar siswa. Begitu pula jika pihak manajemen sekolah kurang memperhatikan optimalisasi penggunaan sumber belajar tersebut dalam proses pembelajaran, penambahan sumber belajar berupa perpustakaan dan laboratorium tidak akan membantu.

Menurut Rosyada (2004) aktivitas guru di dalam kelas meliputi: (1) guru harus membuat rencana pembelajaran yang bijaksana; (2) guru harus mampu berkomunikasi secara efektif dengan siswa; (3) guru harus mengembangkan strategi pembelajaran untuk mengajar; (4) guru harus menguasai kelas; (5) guru harus mengevaluasi dengan benar. Menurut Purwanto (2003) berpartisipasi dalam bidang administrasi, dimana dalam bidang administrasi guru memiliki kesempatan yang cukup untuk mengikuti kegiatan sekolah, antara lain: (1) Mengembangkan konsep pendidikan; (2) Meningkatkan dan menyesuaikan kurikulum; (3) Mengembangkan rencana pengawasan; (4) Perencanaan kebijakan kepegawaian. Semua pekerjaan harus diselesaikan oleh satu guru dengan guru lainnya bersama-sama, yaitu melalui musyawarah. Untuk meningkatkan kinerja, guru harus memeriksa status pemimpin (kepala sekolah). Oleh karena itu, dapat disimpulkan bahwa kualitas guru dalam proses pembelajaran dipengaruhi oleh beberapa faktor, salah satunya adalah kemampuan supervisi yang dilakukan supervisor atau supervisi kinerja guru.

\section{Perilaku Kewarganegaraan Organisasi Guru}

Organizational Citizenship Behavior (OCB) diterjemahkan perilaku kewarganegaraan organisasi (PKO) dalam bahasa Indonesia, adalah kontribusi "di atas dan di luar" pekerja untuk deskripsi pekerjaan formal (Smith et al., dalam Titisari, 2014). Perilaku kewarganegaraan organisasi adalah kontribusi pribadi yang melampaui persyaratan peran di tempat kerja. Ini juga melibatkan beberapa perilaku, termasuk 
membantu orang lain dan partisipasi sukarela.Untuk tugas tambahan, harap ikuti aturan dan prosedur tempat kerja (Titisari, 2014).

Organ, Podsakoff, \& MacKenzie (2005) mendefinisikan perilaku kewarganegaraan organisasi sebagai perilaku bebas, perilaku pribadi tidak secara langsung atau jelas terkait dengan sistem penghargaan, yang dapat meningkatkan operasi organisasi yang efektif. Perilaku kewarganegaraan organisasi (OCB) juga biasanya didefinisikan sebagai perilaku yang melampaui kewajiban formal (peran ekstra) tidak terkait dengan kompensasi langsung. Prinsip dasar munculnya perilaku kewarganegaraan organisasi tidak terlepas dari fenomena yang disebut "warga negara yang baik". Warga negara yang baik adalah orang-orang yang membantu tetangga, memilih, berpartisipasi dalam kegiatan komunitas, dll. Dengan kata lain, seseorang melakukan tindakan yang tidak perlu tetapi berkontribusi pada kesejahteraan masyarakat (Komalasari, Nasih, \& Prasetio, 2009). Artinya orang dengan perilaku organisasional yang tinggi tidak akan mendapatkan bayaran dalam bentuk uang atau bonus tertentu, tetapi perilaku kewarganegaraan organisasi lebih pada perilaku sosial dimana pekerjaan setiap orang melebihi ekspektasi, seperti membantu rekan kerja secara sukarela menunda rapat sebagai sebuah contoh. Guru dengan perilaku warga organisasi yang tinggi akan dapat melaksanakan kegiatan belajar mengajar secara efektif dan efisien, dan pada akhirnya meningkatkan kinerja guru.

Menurut Podsakoff, MacKenzie, Paine, \& Bachrach (2000) PKO akan mempengaruhi keefektifan organisasi pada bidang tertentu. Pertama-tama, PKO dapat membantu rekan kerja kita untuk bekerja dengan baik di lingkungan kerja. Kedua, PKO dapat meningkatkan efisiensi pengelolaan. Ketiga, DPKO akan membantu secara efektif meningkatkan penggunaan sumber daya organisasi untuk alasan produksi. Keempat, PKO dapat mengurangi sumber daya organisasi yang dibutuhkan untuk pemeliharaan karyawan. Kelima, Departemen Penjaga Perdamaian dapat secara efektif mengoordinasikan aktivitas antar anggota tim dan kelompok kerja. Keenam, PKO dapat meningkatkan kemampuan organisasi untuk mempekerjakan dan mempertahankan karyawan yang memenuhi syarat dengan mempromosikan organisasi sebagai tempat kerja yang menarik. Ketujuh, PKO dapat meningkatkan stabilitas kinerja organisasi. Akhirnya, PKO dapat meningkatkan kemampuan organisasi untuk beradaptasi dengan lingkungan bisnis yang berubah.

Sinha (2009) mengemukakan sudut pandang berikutnya, yaitu, "perilaku kewarganegaraan organisasi berarti mengambil tanggung jawab atas suatu organisasi dan melakukan segala upaya untuk membantu menciptakan organisasi yang lebih baik." Lebih lanjut, Sinha percaya bahwa perilaku kewarganegaraan organisasi berarti mengambil tanggung jawab atas organisasi Anda dan melakukan segala kemungkinan untuk membantu membangun organisasi yang lebih baik. Pandangan McShane \& Von Glinow (2010) mendukung pandangan ini, dan mereka menunjukkan bahwa "OCB adalah dukungan dari berbagai bentuk kerjasama dan bantuan kepada orang lain dalam lingkungan sosial dan psikologis suatu organisasi." Pendapat tersebut menjelaskan bahwa OCB merupakan berbagai bentuk kerjasama yang dapat membantu sesama mendukung lingkungan sosial dan psikologis organisasi.

Pandangan Sinha menekankan bahwa guru dan pendidik dengan OCB yang lebih tinggi akan bertanggung jawab atas segalanya untuk menjadikan sekolah lebih baik. Jika sekolah menemui kesulitan dalam mencapai visinya, guru dan pendidik dengan OCB lebih tinggi akan enggan. Mereka secara sukarela akan memberikan kontribusi terbesar 
untuk mewujudkan visi sekolah dengan sebaik-baiknya. Pada saat yang sama, McShane dan Glinow (2010) menekankan bahwa guru dan pendidik dengan OCB yang lebih tinggi akan selalu bekerja sama untuk mewujudkan visi sekolah. Sebagai sebuah organisasi, sekolah tentunya membutuhkan kerjasama yang baik dari seluruh warga sekolah untuk mewujudkan visi sekolah tersebut. Hasil penelitian Eyupoglu (2016) menunjukkan bahwa perilaku OCB memiliki pengaruh yang baik terhadap institusi pendidikan. Institusi pendidikan yang ingin bertahan harus menghadirkan OCB.

Fakta menunjukkan bahwa organisasi dengan perilaku kewarganegaraan organisasi (OCB) yang baik dengan karyawannya akan berkinerja lebih baik daripada organisasi lain (Robbins \& Judge, 2008, hal. 40). Mengenai indikator perilaku kewarganegaraan organisasional, Organ dalam Herminingsih (2012, hal. 128-129) berpendapat bahwa perilaku sipil atau peran tambahan diwujudkan melalui lima bentuk perilaku, yaitu: (1) Altruisme (tindakan membantu orang lain) adalah inti dari kepedulian terhadap kepentingan orang lain, seperti membantu rekan baru dan menyediakan waktu untuk orang lain. Aspek ini mengarah pada bantuan, yang bukan merupakan kewajibannya, (2) conscientiousness (rajin dan hati-hati atau disiplin) adalah perilaku pencegahan, seperti penggunaan waktu yang efektif dan kehadiran yang tinggi. Perilaku ini berupaya untuk melebihi ekspektasi perusahaan atau perilaku sukarela, daripada kewajiban atau pekerjaan karyawan, (3) sportmanship (sportivitas) adalah memaksimalkan total waktu yang dihabiskan untuk pekerjaan konstruktif dalam organisasi. Dapat mentolerir situasi ideal dalam organisasi tanpa menimbulkan perbedaan pendapat. Sportivitas akan menciptakan suasana yang positif di antara karyawan, dan karyawan akan lebih santun serta bekerja sama dengan sesama sehingga menciptakan lingkungan kerja yang lebih menyenangkan, (4) countesy (menjaga hubungan baik) Menjaga hubungan baik dengan rekan kerja untuk menghindari masalah interpersonal. Seseorang dengan dimensi ini adalah seseorang yang menghormati dan peduli pada orang lain, seperti bersikap sopan, patuh kepada rekan kerja bahkan atasan, (5) civic virtue (kebijaksanaan pekerja) adalah perilaku yang menunjukkan tanggung jawab terhadap kehidupan organisasi, seperti mengikuti perubahan dalam organisasi, melakukan tindakan proaktif untuk menyarankan bagaimana memperbaiki operasi atau prosedur organisasi, dan melindungi sumber daya yang dimiliki oleh organisasi. Dimensi ini mengarahkan organisasi untuk memberikan tanggung jawab kepada seseorang untuk meningkatkan kualitas wilayah kerja tempat mereka bekerja.

Borman dan Motowidlo dalam Novliadi (2007, hal. 6) mengungkapkan bahwa perilaku kewarganegaraan organisasi dapat meningkatkan kinerja organisasi, karena perilaku inilah yang menjadi "pelumas" mesin sosial dalam organisasi. Dengan kata lain, melalui perilaku ini maka interaksi sosial organisasi menjadi lebih lancar., mengurangi terjadinya perselisihan, dan meningkatkan efisiensi. Guru dan pendidik yang menerapkan OCB akan mampu meningkatkan kinerjanya. Nasir et al. (2011) mengemukakan bahwa perilaku kewargaan organisasional berdampak pada kinerja. Oleh karena itu, perilaku OCB sangat penting bagi guru dan pendidik.

Oktavianti, Dacholfany, \& Sutanto (2019) menyatakan bahwa dalam bidang pendidikan, perilaku kewarganegaraan organisasi melibatkan membantu sesama dan menjadi upaya untuk menyelesaikan tugas tambahan serta mematuhi aturan dan prosedur tempat kerja. Perilaku kewarganegaraan organisasi dapat meningkatkan kinerja guru, karena perilaku ini merupakan interaksi sosial setiap anggota, yang nantinya dapat membuat semua orang stabil di sekolah, mengurangi terjadinya perselisihan, dan tentunya 
meningkatkan efisiensi. Menurut Triandani (2017) perilaku kewarganegaraan organisasi merupakan kontribusi pribadi yang melebihi persyaratan peran pekerjaan dan dihargai oleh penerima kinerja tugas. Menurut Ticoalu (2013) perilaku pribadi adalah bebas dan tidak langsung atau pengakuan eksplisit sistem penghargaan dan mempromosikan operasi organisasi yang efektif.

Berdasarkan pandangan di atas, maka dapat diketahui bahwa konsep OCB guru dan pendidik adalah upaya sukarela yang melebihi tugas pokok, tanggung jawab dan fungsinya. Bentuk tindakan terhadap tugas pokok dan fungsi dapat berupa meluangkan lebih banyak waktu untuk melayani siswa. Bentuk lain adalah mau berbagi keterampilan dan pengetahuan dengan siswa lain. Untuk setiap guru atau karyawan dengan perilaku warga organisasi internal, upaya pengendalian guru akan berkurang, karena guru dapat mengontrol perilakunya sendiri dan dapat memilih perilaku terbaik untuk kepentingan organisasi, yang dapat lebih meningkatkan kinerja guru.

Dalam kaitannya dengan lembaga pendidikan, perilaku kewarganegaraan guru dan pendidik menekankan bagaimana guru dan pendidik memberikan waktu ekstra untuk tugas pokoknya. Misalnya, guru secara sukarela membimbing siswa untuk menyelesaikan pekerjaan rumah. Ketika beberapa siswa sangat membutuhkan waktu ekstra untuk mencari buku di perpustakaan, pustakawan akan menyediakan lebih banyak waktu

\section{Faktor-Faktor Yang Mempengaruhi Perilaku Kewargaan Organisasi Profesi Guru}

Beberapa faktor yang dapat mempengaruhi perilaku kewargaan organisasi guru (Jayadi, 2012; Titisari, 2014), yaitu: pertama, kepuasan kerja adalah penentu utama perilaku kewarganegaraan organisasi karyawan. Karyawan yang puas lebih cenderung berkomentar positif tentang organisasi, membantu rekan kerja, dan melebihi ekspektasi kinerja kerja normal. Oleh karena itu, karyawan lebih bersedia untuk mematuhi tugasnya karena mereka ingin mengulangi pengalaman positif mereka. Kedua, komitmen organisasi merupakan faktor lain yang berperan dalam membentuk perilaku kewargaan organisasi. Komitmen afektif merupakan indikator prediktif dari perilaku kewargaan organisasional, sehingga komitmen organisasi memiliki pengaruh yang besar terhadap munculnya perilaku kewargaan organisasional.

Ketiga, kepribadian, perbedaan individu adalah prediktor yang berperan penting dalam diri karyawan, oleh karena itu karyawan akan menunjukkan perilaku kewargaan organisasinya, sehingga dapat dianggap bahwa beberapa orang yang menunjukkan kepribadian lebih cenderung menunjukkan perilaku kewargaan organisasionalnya. Keempat, kepemimpinan transformasional mendorong karyawan untuk mengikuti visi organisasi dan memotivasi mereka untuk mencoba mencapai tujuan tersebut dengan menunjukkan perilaku organisasi yang diinginkan. Karyawan akan memberikan kontribusi diluar tanggung jawab formal (PKO) karena mereka termotivasi untuk mencapai visi organisasi tanpa meminta imbalan. Keenam, Kualitas hubungan atasanbawahan, Perilaku kewarganegaraan organisasi juga dipengaruhi oleh hubungan antara atasan dan bawahan yang terjalin selama ini. Semakin dekat bawahan dengan atasan, semakin tinggi kepercayaan atasan dan perhatian atasan, semakin tinggi perilaku sipil organisasi karyawan.

Ketujuh, suasana organisasi mungkin menjadi alasan penting untuk pengembangan perilaku warga organisasi. Dalam suasana organisasi yang positif, karyawan akan lebih berkeinginan untuk melakukan pekerjaan daripada yang tertera pada job description, dan 
jika diperlakukan oleh pemimpin yang unggul dengan semangat yang unggul dan pengetahuan yang lengkap, serta selalu percaya pada tujuan organisasi, dan mereka akan percaya organisasi memperlakukan mereka dengan adil. Ketujuh, budaya organisasi yang kuat akan mempengaruhi keintiman karyawan untuk mencapai tujuan organisasi, sehingga budaya organisasi yang kuat dapat memperoleh kondisi yang baik dan mendukung munculnya perilaku warga organisasi.

\section{Evaluasi Kinerja Guru}

Evaluasi kinerja adalah metode dan proses untuk mengevaluasi kinerja seseorang atau sekelompok orang atau unit kerja di suatu perusahaan atau organisasi berdasarkan standar atau tujuan kinerja yang ditentukan sebelumnya (Simanjuntak, 2005, hal. 103). Sejalan dengan hal tersebut, Uno \& Lamatenggo (2012, hal. 12) meyakini bahwa evaluasi kinerja adalah proses pengukuran kinerja individu, yang selalu membandingkan proses evaluasi dengan standar, sasaran/indikator atau standar yang telah ditentukan dan ditetapkan sebelumnya. Menurut Wirawan (2014, hal. 11) evaluasi kinerja adalah proses mengevaluasi kinerja yang berharga, dan dokumen yang didokumentasikan secara formal adalah untuk mengevaluasi kinerja yang berharga dengan membandingkan standar kinerja secara teratur untuk membantu pengambilan keputusan manajemen sumber daya manusia. Sementara itu, Nawawi (2006, hal. 73) berpendapat bahwa penilaian kinerja juga diartikan sebagai kegiatan mengukur/mengevaluasi kinerja suatu pekerjaan untuk menentukan berhasil tidaknya suatu pekerjaan dalam melaksanakan tugasnya di wilayah kerjanya masing-masing.

Menurut Peraturan Menteri Negara Pemberdayaan Aparatur Negara dan Referomasi Birokrasi Nomor 16 Tahun 2009 mengenai Jabatan Fungsional Guru dan Angka Kreditnya, evaluasi kinerja guru merupakan evaluasi terhadap jabatan, pelatihan jabatan dan jabatan setiap item dalam kegiatan tugas pokok guru. Tugas utama guru sebagai pendidik vokasi adalah mendidik, mengajar, membimbing, melatih, dan menilai peserta didik melalui pendidikan formal pada pendidikan anak usia dini, pendidikan dasar dan pendidikan menengah. Evaluasi kinerja guru mempunyai dua fungsi pokok, yaitu: (1) Menilai kinerja guru dalam tugas pokok dalam proses pembelajaran yang diterapkan, dan kinerja semua kemampuan yang ditunjukkan dalam membimbing atau melaksanakan tugas-tugas lain yang berkaitan dengan fungsi sekolah/madrasah. Oleh karena itu, hasil evaluasi kinerja menjadi profil kinerja guru yang mampu menggambarkan kekuatan dan kelemahan guru. Profil kinerja guru juga dapat diartikan sebagai analisis kebutuhan atau review keterampilan masing-masing guru, yang dapat digunakan sebagai dasar perencanaan pengembangan profesional berkelanjutan guru, (2) Menghitung kredit yang diperoleh guru dalam belajar, mengajar, atau melaksanakan tugas-tugas lain yang berkaitan dengan fungsi sekolah/madrasah selama tahun pelaksanaan evaluasi kinerja guru; sebagai bagian dari proses pengembangan profesional dan promosi guru, evaluasi kinerja akan dilakukan setiap tahun untuk mempromosikan guru dan mempertahankan posisinya.

Hasil evaluasi kinerja guru diharapkan dapat membantu menentukan berbagai kebijakan terkait peningkatan kemampuan dan profesionalisme guru sebagai pedoman pelaksanaan proses pendidikan untuk menumbuhkan individu yang cerdas, komprehensif, dan berdaya saing tinggi. Evaluasi kinerja guru menjadi acuan bagi sekolah/madrasah untuk mengetahui perkembangan profesionalitas dan promosi guru.

\section{JURNAL KEWARGANEGARAAN}


Menggabungkan konten di atas, evaluasi kinerja guru harus didasarkan pada standar kemampuan guru. Suparlan (2006) mengatakan standar kompetensi guru dapat diartikan sebagai "ukuran yang ditetapkan atau ukuran yang diperlukan". Lebih lanjut ditegaskan bahwa "Standar Kompetensi Guru" merupakan ukuran yang ditentukan atau dipersyaratkan dengan cara penguasaan pengetahuan dan perilaku, agar guru memiliki kualifikasi untuk menduduki jabatan sesuai dengan jabatan, kualifikasi dan tingkat pendidikannya. Berdasarkan definisi tersebut, standar kompetensi guru dibedakan menjadi tiga komponen yang saling berkaitan, yaitu: (1) manajemen pembelajaran, (2) pengembangan professional, (3) kemahiran akademis.

Peraturan Pemerintah Republik Indonesia Nomor 19 Tahun 2005 Tentang Standar Nasional Pendidikan menyebutkan bahwa terdapat tiga komponen standar kompetensi guru yang masing-masing terdiri atas beberapa kemampuan, komponen pertama terdiri dari empat kemampuan, dan komponen kedua satu kemampuan, dan komponen ketiga mencakup dua kemampuan. Oleh karena itu, ketiga komponen tersebut secara umum mencakup 7 (tujuh) kemampuan dasar, yaitu: (1) buat rencana studi, (2) menerapkan interaksi pengajaran, (3) evaluasi kinerja siswa, (4) melaksanakan tindak lanjut hasil evaluasi kinerja siswa, (5) pengembangan professional, (6) pemahaman wawasan pendidikan, (7) menguasai materi penelitian akademik yang sesuai dengan mata pelajaran yang diajarkan.

Cari calon karyawan yang berhak dipromosikan, dan tulis saran lain, seperti reward, berdasarkan hasil diskusi antara karyawan dengan pimpinannya. Oleh karena itu, evaluasi kinerja adalah cara untuk mengoreksi mereka yang tidak berprestasi baik dalam organisasi. Dalam suatu organisasi, kemampuan untuk memperoleh posisi terbaik dan terpercaya dalam organisasi sangat bergantung pada pelaksanaan organisasi yaitu karyawan (Mangkunegara, 2004, hal. 67). Tugas utama guru sebagai pendidik vokasi yaitu mendidik, mengajar, membimbing, melatih dan mengevaluasi siswa pada pendidikan anak usia dini melalui pendidikan formal, pendidikan dasar dan pendidikan menengah. Selain tugas pokok tersebut, guru juga dapat melaksanakan tugas lain yang berkaitan dengan fungsi sekolah/madrasah.

Dalam "Pedoman Pelaksanaan Evaluasi Kinerja Guru" Kementerian Pendidikan dan Kebudayaan (2012), evaluasi kinerja guru kelas/mata pelajaran dan tutor dilakukan dengan mengacu pada dimensi tugas pokok guru, meliputi perencanaan dan pelaksanaan pembelajaran dan evaluasi, termasuk analisis hasil evaluasi dan melakukan tindak lanjut hasil evaluasi. Kemudian lingkup tugas pokok ini diturunkan sebagai indikator kinerja yang terukur, sebagai wujud kinerja pada saat guru melaksanakan tugas pokoknya, untuk mencerminkan kemampuan guru, khususnya kemampuan mengajar dan profesional.

Mengembangkan alat evaluasi kinerja untuk guru kelas/mata pelajaran dan guru $\mathrm{BK} /$ konselor, yang mencakup tiga (3) dimensi tugas pokok dengan indikator kinerja. Untuk setiap indikator kinerja setiap item tugas pokok, aturan evaluasi yang lebih rinci akan digunakan untuk mengevaluasi apakah kinerja kepemilikan kapabilitas terlihat dalam dokumen perencanaan (termasuk dokumen pendukung lainnya) dan hasil dari observasi yang dilakukan selama pengamatan pembelajaran.

Sedangkan evaluasi kinerja guru terkait tugas tambahan terkait fungsi sekolah/madrasah dibagi menjadi dua kelompok, yaitu: pertama, tugas lain untuk mengurangi waktu mengajar tatap muka meliputi: (a) kepala sekolah/madrasah, (b) wakil kepala sekolah/pesantren, (c) penanggung jawab rencana profesional/rencana studi, (d) 
pustakawan, (e) penanggung jawab laboratorium, bengkel, unit produksi, dan lain-lain. Kedua, tugas lain yang tidak akan mengurangi waktu mengajar tatap muka meliputi: (a) tugas lain setidaknya selama satu tahun (misalnya, melayani sebagai guru kelas, pengawas perencanaan induksi, dan lain-lain), (b) tugas lain yang kurang dari satu tahun (misalnya, menjadi pengawas penilaian dan evaluasi pembelajaran, penyusunan kurikulum, dan lain-lain).

Untuk guru yang menggunakan tugas tambahan untuk mengurangi waktu pengajaran tatap muka, evaluasi kinerja dievaluasi menggunakan alat khusus yang dirancang sesuai dengan dimensi tugas utama yang diperlukan untuk melakukan tugas tambahan ini. Serupa dengan evaluasi kinerja dan bimbingan guru belajar mengajar, evaluasi kinerja tugas tambahan juga menjelaskan secara rinci dimensi tugas utama sebagai indikator performa yang bias dipantau dan/atau diamati. Menurut Peraturan Menteri Negara Pemberdayaan Aparatur Negara dan Reformasi Birokrasi Nomor 16 Tahun 2009 tentang Jabatan Fungsional Guru dan Angka Kreditnya, pemberian peringkat kredit dapat langsung memberi penghargaan pada tugas lain yang tidak mengurangi waktu mengajar guru.

\section{PENUTUP}

Guru adalah pendidik profesional yang tugas utamanya mendidik, membimbing, mengajar, melatih, mengevaluasi, dan mengevaluasi peserta didik pada pendidikan formal, pendidikan dasar, pendidikan menengah, dan pendidikan anak usia dini (PAUD). Hak guru berupa kebebasan, yaitu sesuai dengan prinsip pendidikan, kewajiban guru (yaitu kepatuhan terhadap peraturan perundang-undangan, undang-undang dan kode etik guru, serta keyakinan dan agama) untuk memberikan penilaian dan berpartisipasi dalam penetapan kelulusan, bentuk penghargaan dan/atau sanksi pada peserta didik. Kedudukan guru adalah seorang profesional, yang berperan untuk meningkatkan harkat dan martabat guru dalam pembelajaran, serta mengembangkan sains, teknologi, dan seni dalam meningkatkan kualitas pendidikan nasional. Menerapkan "Undang-Undang guru dan dosen" untuk meningkatkan kesejahteraan dengan memberikan beberapa tunjangan, antara lain gaji dan tunjangan gaji pokok, tunjangan fungsional, dan tunjangan profesi. Selain itu, guru harus memiliki kualifikasi akademik, kemampuan dan sertifikat pendidik.

Untuk mengoptimalkan kinerja guru, kepala sekolah harus memperhatikan profesionalitasnya, karena guru yang labil memiliki kemampuan yang rendah, dan sikap orang dewasa tidak dapat terus ditampilkan di depan siswa untuk meningkatkan kinerja. Selain profesionalisme, komitmen organisasi juga sangat mempengaruhi kinerja guru, sehingga penanggung jawab yayasan harus memperhatikan keadaan keuangan agar guru dapat menjaga keadaan yang teratur. Pada saat yang sama, perilaku kewarganegaraan organisasi memiliki dampak penting pada variabel kinerja guru. Perilaku kewarganegaraan organisasi yang lebih tinggi secara kolektif menunjukkan kinerja guru. Sebaliknya, perilaku warga organisasi yang lebih rendah secara kolektif menunjukkan kinerja guru yang lebih rendah.

Untuk setiap guru atau karyawan dengan perilaku warga organisasi internal, upaya pengendalian guru akan berkurang, karena guru dapat mengontrol perilakunya sendiri dan dapat memilih perilaku terbaik untuk kepentingan organisasi, yang dapat lebih meningkatkan kinerja guru. Dapat disimpulkan bahwa perilaku kewarganegaraan 
organisasi merupakan perilaku sukarela guru sekolah yang melebihi peran wajib dan persyaratan organisasi, oleh karena itu jika dilakukan oleh guru tidak ada sistem penghargaan, tetapi dapat secara efektif memberikan fungsi bagi organisasi.

\section{UCAPAN TERIMA KASIH}

Saya sangat berterima kasih kepada bapak ibu dosen dan seluruh sahabat atas dukungan, perhatian, kritik dan sarannya demi terselesaikannya jurnal kajian ilmiah ini dengan benar. Saya juga ingin berterima kasih kepada para pembaca yang telah meluangkan waktu untuk membaca artikel saya. Apabila ada kesalahan atau kekurangan pada artikel saya, saya mohon maaf, saya sangat menantikan saran-saran konstruktif dari para pembaca agar dapat membuat artikel yang lebih baik lagi kedepannya.

\section{DAFTAR PUSTAKA}

Alisuf, M. S. (1996). Psikologi Pendidikan Berdasarkan Kurikulum Nasional. Jakarta: CV Pedoman Ilmu Jaya.

Astuti, R., \& Dacholfany, M. I. (2016). Pengaruh Supervisi Pengawas Sekolah dan Kepemimpinan Kepala Sekolah terhadap Kinerja Guru SMP di Kota Metro Lampung. Jurnal Lentera Pendidikan Pusat Penelitian LPPM UM METRO, 1(2), 204-217.

Danim, S. (2010). Profesionalisasi dan Tika Profesi Guru. Bandung: Alfabeta.

Eyupoglu, S. Z. (2016). The Organizational Citizenship Behaviour of Academic Staff in North Cyprus. Procedia Economics and Finance, 39, 701-704.

Herminingsih, A. (2012). Spiritualitas Dan Kepuasan Kerja Sebagai Faktor Organizational Citizenship Behavior (OCB). Jurnal Ilmu Ekonomi dan Sosial, 1(2), 126-14.

Heryati, Y., \& Muhsin, M. (2014). Manajemen Sumber Daya Pendidikan. Bandung: Pustaka Setia.

Jalal, F., \& Supriadi, D. (Ed.). (2001). Reformasi Pendidikan Dalam Konteks Otonomi Daerah. Diterbitkan atas kerjasama Depdiknas, Bappenas, Adicita Karya Nusa.

Jayadi, J. (2012). Kompetensi Guru, Spiritual Intelligence, Self Determination Theorydan Organization Citizenship Behavior. HUMANITAS: Indonesian Psychological Journal, 9(2), 169-184.

Kartini, K. (1985). Menyiapkan Memadukan Karir. Jakarta: CV Rajawali.

Kebudayaan, K. P. dan. (2012). Pembinaan Dan Pengembangan Profesi Guru Buku 2: Pedoman Pelaksanaan Penilaian Kinerja Guru. Jakarta: Kementerian Pendidikan dan Kebudayaan.

Komalasari, P. T. T., Nasih, M., \& Prasetio, T. (2009). Pengaruh Public Service Motivation dan Organizational Citizenship Behavior Terhadap Kinerja Organisasi Pemerintahan. Jurnal Manajemen Teori dan Terapan $\mid$ Journal of Theory and Applied Management, 2(2). 
Mangkunegara, A. P. (2004). Manajemen Sumber Daya Manusia. Bandung: PT. Remaja Rosdakarya.

Mathis, R. L., \& Jackson, J. H. (2006). Manajemen Sumber Daya Manusia (10 ed.). Jakarta: Salemba Empat.

McShane, S., \& Von Glinow, M. A. (2010). Organizational Behaviour: Emerging Knowledge and Practice for the Real World. McGraw-Hill/Irwin.

Mulyasa, E. (2004). Implementasi Kurikulum 2004 Panduan Pembelajaran KBK. Bandung: Remaja Rosdakarya.

Nasir, R., Mohammadi, M. S., Wan Shahrazad, W. S., Fatimah, O., Khairudin, R., \& Halim, F. (2011). Relationship Between Organizational Citizenship Behavior and Task Performance. The social sciences, 6(4), 307-312.

Nasution, S. (2000). Berbagai Pendekatan Dalam Proses Belajar dan Bengajar. PT. Bina Aksara.

Nawawi, H. (2006). Evaluasi Dan Manajemen Kinerja di Lingkungan Perusahaan dan Industri. Yogyakarta: Gadjah Mada University Press.

Novliadi, F. (2007). Organizational Citizenship Behavior Karyawan Ditinjau dari Persepsi Terhadap Kualitas Interaksi Atasan-bawahan dan Persepsi Terhadap Dukungan Organisasional. Laporan Penelitian, Medan: Universitas Sumatera Utara.

Nur, H. (2009). Pendidik dan Tenaga Kependidikan. Jurnal Medtek, 1(2). https://doi.org/10.26858/publikan.v6i3.2275

Oktavianti, S., Dacholfany, M. I., \& Sutanto, A. (2019). Pengaruh Kepemimpinan Kepala Sekolah dan Perilaku Kewaganegaraan Organisasi Terhadap Kinerja Guru di SMP Se-Kecamatan Purbolinggo Kabupaten Lampung Timur. Jurnal Lentera Pendidikan Pusat Penelitian LPPM UM Metro, 4(2), 58-71.

Organ, D. W., Podsakoff, P. M., \& MacKenzie, S. B. (2005). Organizational Citizenship Behavior: Its Nature, Antecedents, and Consequences. Sage Publications.

Peraturan Manteri Pendidikan Nasional Nomor 41 Tahun 2007 tentang Satuan Pendidikan Dasar dan Menengah.

Peraturan Menteri Negara Pemberdayaan Aparatur Negara dan Referomasi Birokrasi Nomor 16 Tahun 2009 tentang Jabatan Fungsional Guru dan Angka Kreditnya.

Peraturan Pemerintah Republik Indonesia Nomor 19 Tahun 2005 tentang Standar Nasional Pendidikan.

Peraturan Pemerintah Republik Indonesia Nomor 19 Tahun 2017 tentang Perubahan Peraturan Pemerintah Nomor 74 Tahun 2008 tentang Guru.

Pidarta, M. (1992). Pemikiran tentang Supervisi Pendidikan. Jakarta: Bumi Aksara.

Podsakoff, P. M., MacKenzie, S. B., Paine, J. B., \& Bachrach, D. G. (2000). Organizational Citizenship Behaviors: A Critical Review of the Theoretical and Empirical Literature and Suggestions for Future Research. Journal of Management, 26(3), 513-563. https://doi.org/10.1016/s0149-2063(00)00047-7 
Purba, D. E., \& Seniati, A. N. L. (2004). Pengaruh Kepribadian dan Komitmen Organisasi Terhadap Organizational Citizenship Behavior. HUBS Asia, 8(3), 105-111.

Purwanto, M. N. (2003). Administrasi dan Supervisi Pendidikan. Jakarta: Remaja Rosdakarya.

Robbins, S. P., \& Judge, T. A. (2008). Organizational Behavior. New Jersey: Pearson International Edition.

Rosyada, D. (2004). Paradigma Pendidikan Demokratis: Sebuah Model Pelibatan Masyarakat dalam Penyelenggaraan Pendidikan. Jakarta: Kencana.

Rusman. (2009). Manejemen Kurikulum. Jakarta: Raja Grafindo Persada.

Simanjuntak, P. J. (2005). Manajemen dan Evaluasi Kinerja. Jakarta: Fe UI.

Sinha, J. B. P. (2009). Culture and Organizational Behaviour. SAGE Publications India.

Supadi, \& Listyasari, W. D. (2018). Hubungan Antara Lingkungan Kerja dan Motivasi dengan Organizational Citizenship Behavior (OCB) Guru di SMA Negeri Se Jakarta Timur. IMPROVEMENT: Jurnal Ilmiah Untuk Peningkatan Mutu Manajemen Pendidikan, 5(1), 110-118. https://doi.org/10.21009/IMPROVEMENT.051.10

Supardi. (2016). Kinerja Guru. Jakarta: PT. Raja Grafindo Persada.

Suparlan, M. (2006). Guru sebagai Profesi. Yogyakarta: Hikayat Publising.

Supriyatno, A., Subiyanto, \& Tawil. (2016). Pengaruh Sertifikasi Pendidik, Kompetensi Guru dan Kepemimpinan Kepala Sekolah Terhadap Kinerja Guru SMA. Jurnal Profesi Pendidik, 3(2), 171-181.

Syah, M., Wardan, A. S., Rakhmat, M. F., \& Muchlis. (1997). Psikologi Pendidikan: Dengan Pendekatan Baru. Penerbit PT Remaja Rosdakarya.

Ticoalu, L. K. (2013). Organizational Citizenship Behavior (OCB) dan Komitmen Organisasi Pengaruhnya Terhadap Kinerja Karyawan. Jurnal EMBA: Jurnal Riset Ekonomi, Manajemen, Bisnis dan Akuntansi, 1(4), 782-790.

Titisari, P. (2014). Peranan Organizational Citizenship Behavior (OCB) dalam Meningkatkan Kinerja Karyawan. Bogor: Mitra Wacana Media.

Triandani, S. (2017). Pengaruh Organizational Citizenship Behavior (OCB) Terhadap Kinerja Karyawan Pada PT. Inti Kharisma Mandiri Riau Pekanbaru. Jurnal AlIqtishad, 10(1), 18-25.

Undang-Undang Dasar Negara Republik Indonesia Tahun 1945.

Undang-Undang Republik Indonesia Nomor 14 Tahun 2005 tentang Guru.

Undang-Undang Republik Indonesia Nomor 20 Tahun 2003 tentang Sistem Pendidikan Nasional.

Uno, H. B., \& Lamatenggo, N. (2012). Teori Kinerja Dan Pengukurannya. Jakarta: PT. Bumi Aksara.

Wirawan, I. (2014). Pengaruh Karakteristik Pemerintah Daerah dan Temuan Audit Badan Pemeriksa Keuangan Terhadap Kinerja Penyelenggaraan Pemerintahan 
Daerah Kabupaten/Kota Di Indonesia Tahun Anggaran 2012. UNS (Sebelas Maret University).

Yamin, M. (2010). Standarisasi Kinerja Guru. Jakarta: Gaung Persada 14. 